\title{
Pengaruh Rasio Kecukupan Modal, Likuiditas, Risiko Kredit dan Efisiensi Biaya Terhadap Profitabilitas Pada Bank Go Public
}

\author{
Uli Wildan Nuryanto' ${ }^{1}$, Anis Fuad Salam², Ratih Purnama Sari ${ }^{3}$, Dede Suleman ${ }^{4}$ \\ ${ }^{1,2,3}$ Sekolah Tinggi Ilmu Ekonomi Banten (STIE Banten) \\ 1uiwildan@stiebanten.ac.id, ${ }^{2}$ anis.f.salam@stiebanten.ac.id, ${ }^{3}$ ratih.purnamasari@yahoo.com \\ ${ }^{4}$ Universitas Bina Sarana Informatika (UBSI) \\ 4dede.dln@bsi.ac.id

\begin{tabular}{ccc}
\hline Diterima & Direvisi & Disetujui \\
$27-10-2019$ & $21-11-2019$ & $01-12-2019$ \\
\hline
\end{tabular}

\begin{abstract}
Abstrak - Peningkatan pertumbuhan ekonomi ini tidak serta merta meningkatkan profitabilitas bank di Indonesia. Ada tiga masalah mendasar yang telah digali oleh Lembaga Penjamin Simpanan (LPS) untuk bank, antara lain, penurunan suku bunga bank pertama yang terus-menerus menyebabkan margin bunga bank menjadi tipis. Kedua, beban regulasi mengharuskan bank untuk menyisihkan modal untuk cadangan modal bank tambahan dan ketiga potensi peningkatan risiko kredit macet karena ketidakpastian ekonomi global dan pemulihan ekonomi domestik yang tidak merata. Untuk alasan ini, penelitian ini dilakukan untuk mengetahui seberapa besar profitabilitas bank domestik yang terdaftar di Bursa Efek Indonesia pada periode 2014-2018 dan juga hubungan antara prediktor internal yang, menurut studi review, memiliki pengaruh signifikan terhadap profitabilitas . Populasi dalam penelitian ini adalah 43 bank yang terdaftar di Bursa Efek Indonesia pada periode 2014-2018 sedangkan sampelnya adalah 10 bank yang terdaftar di BEI dengan jumlah aset terbesar menurut Bank Indonesia menggunakan metode purposive sampling. Hasil penelitian menunjukkan CAR, LDR, NPL dan BOPO yang signifikan mempengaruhi ROA. Sedangkan secara parsial LDR, NPL dan BOPO memiliki pengaruh signifikan terhadap ROA sedangkan CAR tidak memiliki pengaruh signifikan. Besarnya pengaruh variabel prediktor terhadap profitabilitas menggunakan koefisien determinasi yang diperoleh sebesar $74,2 \%$ sedangkan sisanya $25,8 \%$ dipengaruhi oleh variabel lain di luar model penelitian ini.
\end{abstract}

Kata kunci: Rasio Kecukupan Modal (CAR), Rasio Likuiditas (LDR), Risiko Kredit (NPL), Efisiensi Biaya Operasional (BOPO), Profitabilitas (ROA).

\begin{abstract}
This increase in economic growth does not necessarily increase the profitability of banks in Indonesia. There are three fundamental problems that have been unearthed by the Deposit Insurance Corporation (LPS) for banks, among others, the first decline in bank interest rates continuously causing bank interest margins to thin. Second, the regulatory burden requires banks to set aside capital for additional bank capital reserves and thirdly the potential increase in the risk of non-performing loans due to global economic uncertainty and the uneven recovery of the domestic economy. For this reason, this research was conducted to find out how much profitability of domestic banks listed on the Indonesia Stock Exchange in the period 20142018 and also the relationship between internal predictors which, according to the review study, had a significant effect on profitability. The population in this study were 43 banks listed on the Indonesia Stock Exchange in the 2014-2018 period while the sample was 10 banks listed on the IDX with the largest number of assets according to Bank Indonesia using the purposive sampling method. The results showed a significant CAR, $L D R, N P L$ and BOPO significantly influence ROA. While partially LDR, NPL and BOPO have a significant effect on ROA while CAR has no significant effect. The magnitude of the effect of the predictor variable on profitability using the coefficient of determination obtained by $74.2 \%$ while the remaining $25.8 \%$ is influenced by other variables outside this research model.
\end{abstract}

Keywords: Capital Adequacy Ratio (CAR), Liquidity Ratio (LDR), Credit Risk (NPL), Operational Cost Efficiency (BOPO). Profitability (ROA). 


\section{PENDAHULUAN}

Bank memiliki peranan penting bagi perekonomian nasional. Menurut Wijaya dan Tiyas (2016), bank merupakan jantung perekonomian Nasional, hal ini dikarenakan uang yang mengalir ke bank kemudian diedarkan kembali oleh bank ke sistem perekonomian untuk menjalankan kegiatan perekonomian. Semakin berkembangnya suatu bank akan diiringi oleh oleh tantangan yang harus dihadapi oleh bank sebagai Lembaga keuangan yang berdasarkan kepercayaan (agent of trust). Salah satu tantangan dalam menghadapi persaingan bank adalah laporan kinerja keuangannya. Mengingat masyarakat akan menilai dan cenderung untuk memilih bank dengan laporan kinerja keuangan yang lebih baik dengan alasan tingkat risiko yang akan dihadapi akan lebih kecil.

Pada tahun 2018 perekonomian Nasional telah mencapai kinerja pertumbuhan ekonomi yang sangat baik dengan pencapaian sebesar 5,17\% menjadikan tahun 2018 sebagai pertumbuhan ekonmi tertinggi sejak tahun 2014. Namun menurut Lembaga Penjamin Simpanan (LPS), pertumbuhan ekonomi tersebut tidak begitu saja menjadikan industri perbankan di Tanah Air mendapatkan profitabilitas yang bersifat meningkat drastis, mengingat terdapat beberapa kendala yang dihadapi oleh industri perbankan di Tanah Air. Diantaranya adalah menurunnya suku bunga perbankan secara terus menerus, hal ini menyebabkan marjin bunga bank menipis sehingga pihak perbankan dituntut untuk mencari dana dari sumber pendapatan lain. Kendala berikutnya adalah beban regulasi yang mewajibkan bank menyisihkan modal penambahan cadangan modal perbankan dengan tujuan memitigasi pasar keuangan global yang berpotensi mengganggu kestabilan bank, hal ini akan mengurangi tingkat profitabilitas bank mengingat sebagian marjin yang ada akan terpakai sebagai cadangan modal. Kendala ketiga adalah potensi kenaikan risiko akibat kredit bermasalah atau biasa disebut dengan non performance loan (NPL), hal in diakibatkan oleh ketidakpastian global dan pemulihan ekonomi domestik yang belum merata. Kendala-kendala tersebut akan menyebabkan tekanan terhadap laba bank dan diperkirakan akan berkontribusi menyebabkan perlambatan pertumbuhan profit.

Dengan tingginya peran perbankan Nasional bagi perkembangan ekonomi dalam negeri namun juga dihadapi kepada permaslahan yang telah dijelaskan sebelumnya, maka sangatlah penting bagi perbankan di Tanah Air untuk selalu menjaga kinerja keuangannya dengan baik, terutama menjaga rasio keuangan yang oleh masyarakat luas di perhatikan sebagai suatu indikator keberhasilan operasional bank. Diantara rasio tersebut adalah tingkat profitabilitas yang tinggi, tingkat profitabilitas umumnya diukur dengan menggunakan rasio Return on Asset (ROA) yang menggambarkan kemampuan suatu bank untuk memperoleh earning dari kegiatan operasionalnya. Oleh karenanya penelitian tentang analisis faktor-faktor yang mempengaruhi ROA pada perbankan yang terdaftar di Bursa Efek Indonesia tahun 2014-2018 penting untuk dilakukan. Hal ini untuk mengetahui sejauh mana komponen-komponen rasio yang berpengaruh secara signifikan terhadap profitabilitas perbankan sehingga dapat dilakukan deteksi sejak dini terhadap pengaruh yang dapat mengganggu peningkatan terhadap profitabilitas. Dengan analisa ini maka diharapkan bank akan mendapatkan laba yang optimal.

Dengan adanya kesenjangan atau research gap dari hasil penelitian terdahulu sehingga perlu dilakukan penelitian lanjutan, maka peneliti berusaha menggali lebih mendalam terhadap objek penelitian yang akan difokuskan terhadap bank umum yang telah go public serta memiliki asset terbesar menurut Bank Indonesia, dengan rentang waktu periode 5 tahun terakhir. Mengingat bank yang telah go public menyalurkan dana kepada masyarakat dalam bentuk kredit serta memberikan jasa lalu lintas pembayaran serta menjual sebagian sahamnya kepada public. Dengan demikian diharapkan profitability yang didapatkan oleh bank tersebut besar.

Profitabilitas merupakan indikator yang paling penting untuk mengukur kinerja suatu bank. Return on Assets (ROA) memfokuskan kemampuan perusahaan untuk memperoleh earning dalam kegiatan operasi perusahaan dengan memanfaatkan aktiva yang dimilikinya. Sehingga dalam penelitian ini ROA digunakan sebagai ukuran kinerja perbankan. Tujuan utama operasional bank adalah mencapai tingkat profitabilitas yang maksimal. ROA penting bagi bank karena ROA digunakan untuk mengukur efektivitas perusahaan di dalam menghasilkan keuntungan dengan memanfaatkan aktiva yang dimilikinya. Profitabilitas merupakan kemampuan bank untuk menghasilkan / memperoleh laba secara efektif dan efisien. Profitabilitas yang digunakan adalah ROA karena dapat memperhitungkan kemampuan manajemen bank dalam mengelola aktiva yang dimilikinya untuk menghasilkan income. Semakin besar ROA suatu bank, semakin besar pula tingkat keuntungan yang dicapai bank tersebut dan semakin baik pula posisi bank tersebut dari segi penggunaan asset (Syamsuddin, 2013).

Variabel CAR dapat mempengaruhi tingkat profitabilitas perusahaan perbankan. Semakin tinggi CAR maka semakin baik kemampuan bank tersebut untuk menanggung risiko dari setiap aktiva produktif yang berisiko. Jika nilai CAR tinggi maka bank tersebut mampu membiayai kegiatan operasional dan memberikan kontribusi yang cukup besar bagi profitabilitas. Tingginya rasio modal dapat melindungi deposan dan meningkatkan 
kepercayaan masyarakat kepada bank, dan pada akhirnya dapat meningkatkan mendapatan suatu bank (Febrianti \& Ladinus, 2019).

Profitabilitas juga erat kaitannya dengan jumlah kredit yang diberikan yang dilihat menggunakan rasio Loan to Deposit Ratio (LDR). Loan to Deposit Ratio (LDR) adalah rasio antara seluruh jumlah kredit yang diberikan bank dengan dana yang diterima oleh bank. Sesuai dengan ketentuan Bank Indonesia, batas ideal ketentuan rasio kredit terhadap simpanan (LDR) adalah sebesar 78\%-100\% (SE BI No.15/41/DKMP tanggal 1 oktober 2013). Batas ideal ini dibuat sebagai panduan agar bank tidak terlalu agresif dan lebih berhati-hati terhadap potensi terjadinya kredit bermasalah.

Non Performing Loan (NPL) merupakan kredit yang disalurkan, namun kurang lancar, diragukan, dan macet. NPL bertujuan untuk mengetahui kinerja manajemen dalam menggunakan semua aktivitas secara efisien. NPL dapat diketahui dengan cara menghitung pembiayaan Non Lancar Terhadap Total Pembiayaan. Semakin rendah NPL maka bank tersebut akan semakin mengalami keuntungan, sebaliknya tingkat NPL tinggi bank tersebut akan mengalami kerugian yang diakibatkan tingkat kembalian kredit macet. Banyaknya kredit bermasalah menyebabkan terkikisnya permodalan yang dapat dilihat dari angka Capital Adequacy Ratio (Syamsuddin, 2013).

Biaya Operasional Pendapatan Operasional (BOPO) adalah perbandingan antara biaya operasional dengan pendapatan operasional. Biaya operasional merupakan biaya yang dikeluarkan oleh bank dalam rangka menjalankan aktivitas usaha pokoknya (seperti biaya bunga, biaya tenaga kerja, biaya pemasaran, dan lain-lain). Pendapatan operasional merupakan pendapatan utama bank yaitu pendapatan bunga yang diperoleh dari penempatan dana dalam bentuk kredit dan penempatan operasional lainnya.

Bank Indonesia menetapkan ketentuan BOPO bagi Bank Umum Kelompok Usaha (BUKU) I maksimal $85 \%$. BUKU II kisaran 78\%-80\%, BUKU III kisaran 70\%-75\%, dan BUKU IV 60\%-65\%. Secara umum rasio BOPO yang harus dijaga bank umum adalah tidak lebih dari $85 \%$. Semakin kecil BOPO semakin kecil biaya operasional yang dikeluarkan sehingga kemungkinan bank untuk mendapatkan keuntaungan lebih besar.

\section{METODOLOGI PENELITIAN}

Penelitian ini menggunakan pendekatan penelitian kuantitatif sehingga diharapkan mampu untuk memebrikan gambaran melalui penghitungan data-data yang diperoleh mengenai pengaruh CAR, LDR, NPL dan BOPO terhadap ROA pada Lembaga perbankan yang terdaftar di Bursa Efek Indonesia periode tahun 2014-2018.
Sedangkan metode yang digunakan adalah kausal yaitu penelitian dengan karakteristik masalah berupa hubungan sebab akibat antara dua variabel atau lebih. Penelitian ini menggunakan empat variabel independent yaitu rasio kecukupan modal, likuiditas, risiko kredit dan efisiensi biaya. Sedangkan variabel dependen adalah profitabilitas sebagaimana terlihat pada tabel berikut:

Tabel 1. Operasional Variabel Penelitian

\begin{tabular}{|c|c|c|c|}
\hline No & Variabel & Indikator & Skala \\
\hline 1 & $\begin{array}{l}\text { Rasio } \\
\text { Kecukupan } \\
\text { Modal }\end{array}$ & $\mathrm{CAR}=\frac{\text { Modal }}{\text { ATMR }}$ & Rasio \\
\hline 2 & Likuiditas & $\begin{array}{l}\text { LDR } \\
=\frac{\text { Total Kredit }}{\text { Total Dana Pihak Ketiga }} \times 100 \%\end{array}$ & Rasio \\
\hline 3 & $\begin{array}{l}\text { Risiko } \\
\text { Kredit }\end{array}$ & $\begin{array}{l}\text { NPL } \\
=\frac{\text { Kredit yang Bermasalah }}{\text { Total Kredit }} \times 100 \%\end{array}$ & Rasio \\
\hline 4 & $\begin{array}{l}\text { Efisiensi } \\
\text { Biaya }\end{array}$ & $\begin{array}{l}\text { BOPO } \\
=\frac{\text { Biaya Operasional }}{\text { Pendapatan Operasional }} \times 100 \%\end{array}$ & Rasio \\
\hline 5 & Profitabilitas & $\mathrm{ROA}=\frac{\text { Laba Sebelum Pajak }}{\text { Rata }- \text { Rata Total Aset }} \times 100 \%$ & Rasio \\
\hline
\end{tabular}

Sumber : Data primer (2019)

Populasi yang digunakan pada penelitian ini seluruh bank yang terdaftar di Bursa Efek Indonesia (BEI) periode tahun 2014-2018 yang berjumlah 43 bank. Sedangkan sampel pada penelitian ini adalah 10 bank terbesar dalam asset menurut Bank Indonesia yang telah Go Public, dengan menggunakan metode purposive sampling.

Salah satu alasan penggunaan objek penelitian terhadap 10 bank terbesar karena sumber utama pendapatan bank adalah berasal dari kredit dan pendanaan terhadap kerugian akibat risiko yang timbul dari kredit sepenuhnya harus ditanggung sendiri tanpa melibatkan nasabah sehingga membuat bank tersebut rentan mengalami penuruanan profitabilitas. Kegiatan usaha lainnya adalah melayanai lalu lintas pembayaran dan menjual sebagian sahamnya kepada publik di bursa efek Indonesia. Berdasarkan hasil literature review dan juga variabel operasional yang telah ditentukan, maka kerangka penelitian tergambar sebagai berikut:

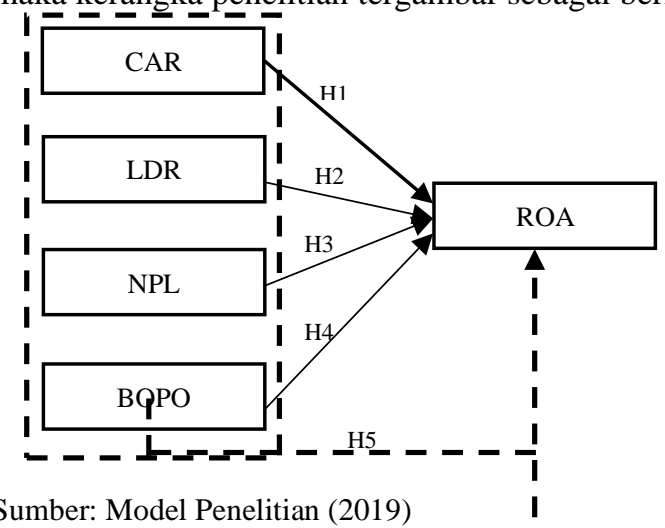

Gambar 1. Kerangka Pemikiran Penelitian 
Metode analisis yang digunakan pada penelitian ini adalah analisis deskriptif, uji asumsi klasik, uji regresi linear berganda, uji koefisien deterinasi, uji hipotesis parsial (uji t) dan uji hipotesis berganda (uji $\mathrm{F}$ ). pengolahan data dilakukan dengan menggunakan program SPSS Versi 22. Berdasarkan kerangka pemikirian penelitian di atas maka didapatkan hipotesis penelitian sebagai berikut:

Hipotesis 1: Secara parsial CAR berpengaruh signifikan terhadap ROA.

Hipoteiss 2: Secara parsial LDR berpengaruh signifikan terhadap ROA.

Hipotesis 3: Secara parsial NPL berpengaruh signifikan terhadap ROA

Hipotesis 4: Secara parsial BOPO berpengaruh signifikan terhadap ROA

Hipotesis 5: $\quad$ Secara simultan, CAR, LDR, NPL dan BOPO berpengaruh signifikan terhadap ROA.

\section{HASIL DAN PEMBAHASAN}

Hasil analisis deskriptif pada penelitian ini didapatkan nilai rata-rata, minimum dan maksimum untuk CAR, LDR, NPL, BOPO dan ROA sebagai berikut:

Tabel 2. Hasil Analisis Deskriptif

\begin{tabular}{|c|c|c|c|c|c|}
\hline & $\mathrm{N}$ & Minimum & Maximum & Mean & $\begin{array}{c}\text { Std. } \\
\text { Deviation }\end{array}$ \\
\hline CAR & 50 & 14,64 & 23,40 & 19,2414 & 2,26688 \\
\hline LDR & 50 & 76,80 & 108,86 & 91,6480 & 7,50032 \\
\hline NPL & 50 &, 60 & 4,01 & 2,4922 &, 83601 \\
\hline BOPO & 50 & 48,80 & 97,38 & 75,1760 & 11,38918 \\
\hline ROA & 50 &, 47 & 4,74 & 2,3758 & 1,06663 \\
\hline $\begin{array}{c}\text { Valid N } \\
\text { (listwise) }\end{array}$ & 50 & & & & \\
\hline
\end{tabular}

Sumber : Output SPSS (2019)

Dari Hasil Analisis Deskriptif didapatkan nilai minimum untuk CAR sebesar 14,64 dan maksimumnya 23,40 dengan nilai rata-rata sebesar 19,24. Untuk variabel LDR didapatkan nilai minium sebesar 76,80 dan maksimum sebesar 108,86 dengan nilai rata-rata sebesar 91,648. Untuk variabel NPL didapatkan nilai minimum sebesar 0,60 dan maksimum sebesar 4,01 dengan nilai rata-rata sebesar 2,492. Untuk variabel BOPO didapatkan nilai minimum sebesar 48,80 dan maksimum sebesar 97,38 dengan nilai rata-rata sebesar 75,17 sedangkan untuk variabel ROA didapatkan nilai minimum sebesar 0,47 dan maksimum sebesar 4,74 dengan nilai rata-rata sebesar 2,375.

Hasil analisis asumsi klasik menggunakan uji normalitas didapatkan hasil berupa tabel Kolmogorov Smirnov sebagai berikut:
Tabel 3. Hasil Uji Normalitas Kolmogorov Smirnov

\begin{tabular}{|l|l|r|}
\hline \multicolumn{2}{|l|}{} & \multicolumn{1}{|c|}{$\begin{array}{c}\text { Unstandardized } \\
\text { Residual }\end{array}$} \\
\hline $\mathrm{N}$ & 50 \\
\hline Normal Parameters & Mean &, 0000000 \\
\cline { 2 - 3 } & $\begin{array}{l}\text { Std. } \\
\text { Deviation }\end{array}$ &, 51881386 \\
\hline \multirow{2}{*}{$\begin{array}{l}\text { Most Extreme } \\
\text { Differences }\end{array}$} & Absolute &, 059 \\
\cline { 2 - 3 } & Positive &, 059 \\
\cline { 2 - 3 } & Negative &,- 053 \\
\hline \multicolumn{2}{|l|}{ Test Statistic } &, 059 \\
\hline \multicolumn{2}{|l|}{ Asymp. Sig. (2-tailed) } &, $200^{\mathrm{c}, \mathrm{d}}$ \\
\hline
\end{tabular}

Sumber : Output SPSS (2019)

Dari hasil Uji Normalitas Kolmogorov Smirnov didapatkan nilai Asymp. Sig (2-tailed) sebesar 0.200 dimana nilai ini lebih besar dari 0,05 sehingga dapat disimpulkan bahwa residual data berdistribusi normal.

Hasil uji asumsi klasik multikolineraitas didapatkan nilai Tolerance dan Variance Inflation Factor (VIF) untuk masing-masing variabel independent sebagai berikut;

Tabel 4. Hasil Uji Multikolinearitas

\begin{tabular}{|l|c|c|}
\hline Variabel & Tolerance & VIF \\
\hline CAR & 0,713 & 1,402 \\
\hline LDR & 0,609 & 1,641 \\
\hline NPL & 0,612 & 1,634 \\
\hline BOPO & 0,488 & 2,050 \\
\hline
\end{tabular}

Sumber : Output SPSS (2019)

Dari hasil Uji Multikolinearitas didapatkan untuk masing-masing variabel independent memiliki nilai Tolerance di bawah berkisar antara 0,10 hingga 1,0 dengan nilai VIF berada dibawah 10 . Hasil ini menunjukan bahwa data bebas multikolinearitas.

Hasil uji asumsi klasik autokorelasi didapatkan nilai Durbin Watson (DW) hitung sebesar 1,810 sebagaimana terlihat pada tabel berikut:

Tabel 5. Model Summary ${ }^{\mathrm{b}}$

\begin{tabular}{|l|c|r|r|r|r|}
\hline Model & $\mathrm{R}$ & $\begin{array}{c}\mathrm{R} \\
\text { Square }\end{array}$ & $\begin{array}{c}\text { Adjusted } \\
\text { R Square }\end{array}$ & $\begin{array}{c}\text { Std. Error of } \\
\text { the Estimate }\end{array}$ & $\begin{array}{c}\text { Durbin- } \\
\text { Watson }\end{array}$ \\
\hline 1 &, $874^{\mathrm{a}}$ &, 763 &, 742 &, 54138 & 1,810 \\
\hline
\end{tabular}

Sumber : Output SPSS (2019)

Dari hasil Model Summary ${ }^{\mathrm{b}}$ didapatkan nilai DW sebesar 1,810 berada pada rentang nilai 4$\mathrm{dL}<\mathrm{DW}<4$-dU sehingga dapat disimpulkan residual data terbebas dari autokorelasi.

Hasil uji asumsi klasik heteroskedastisitas didapatkan grafik scatterplot sebagai berikut: 


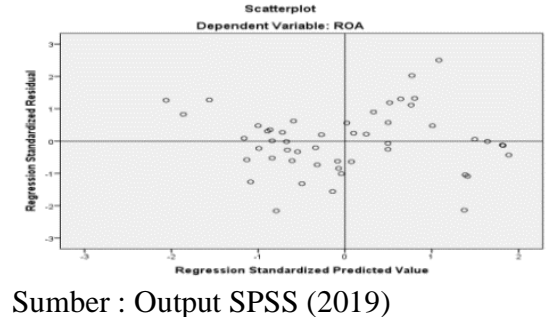

Sumber : Output SPSS (2019)

Gambar 2. Hasil Grafik Scatterplot

Dari hasil grafik di atas didapatkan residual data berdistribusi merata diempat kuadran yang berbeda dan tidak membentuk pola tertentu yang sama. Hasil ini menunjukan bahwa residual data terbebas dari heteroskedastisitas.

Hasil uji regresi linear berganda didapatkan tabel coefficient ${ }^{a}$ sebagai berikut:

Tabel 6. Hasil Uji Regresi Linear Berganda

\begin{tabular}{|c|c|c|c|c|c|c|}
\hline & \multirow{2}{*}{ Model } & \multicolumn{2}{|c|}{$\begin{array}{l}\text { Unstandardize } \\
\text { d Coefficients }\end{array}$} & \multirow{2}{*}{$\begin{array}{c}\text { Standardized } \\
\text { Coefficients } \\
\text { Beta }\end{array}$} & \multirow[t]{2}{*}{$\mathrm{t}$} & \multirow[t]{2}{*}{ Sig. } \\
\hline & & B & $\begin{array}{c}\text { Std. } \\
\text { Error }\end{array}$ & & & \\
\hline \multirow[t]{5}{*}{1} & (Constant) & 9,212 & 1,451 & & 6,348 &, 000 \\
\hline & CAR & ,049 & , 040 & ,104 & 1,215 & ,231 \\
\hline & LDR &,- 037 & ,013 &,- 263 & 2,832 & ,007 \\
\hline & NPL &,- 238 & ,118 &,- 186 & $2,015^{-}$ & ,049 \\
\hline & ВОРО &,- 050 & ,010 &,- 534 & 5,143 & ,000 \\
\hline
\end{tabular}

Sumber : Output SPSS (2019)

Dari tabel Hasil Uji Regresi Linear Berganda didapatkan nilai konstanta regresi sebesar 9,212 dengan nilai koefisien untuk variabel CAR sebesar 0,049, LDR -0,037, NPL sebesar -0,238 dan BOPO sebesar $-0,050$ sehingga didapatkan persamaan regresi sebagai berikut:

ROA $=9,212+0,049$ CAR - 0,037 LDR 0,238 NPL - 0,050 BOPO.

Besarnya nilai Adjusted R square didapatkan sebesar 0,742 sebagaimana terlihat pada tabel 4 . Sehingga daidapatkan nilai koefisien determinasi (Kd) sebesar 74,2\% yang menggambarkan besarnya pengaruh keempat variabel CAR, LDR, NPL dan BOPO terhadap ROA sebesar 74,2\% sedangkan sisanya sebesar $25,8 \%$ adalah pengaruh variabel lainnya diluar model penelitian ini.

Hasil uji hipotesis parsial (uji t) untuk variabel CAR didapatkan nilai $\mathrm{t}$ hitung sebesar 1,215 dengan sig 0,213 , dimana nilai sig > 0,05 sehingga didapatkan bahwa hipotesis ditolak. Sementara untuk variabel LDR didapatkan nilai $\mathrm{t}$ hitung sebesar -2,832 dengan sig 0,007 dimana nilai sig $<0,05$ sehingga didapatkan bahwa hipotesis kedua diterima. Hasil uji hipotesis variabel NPL didapatkan nilai $t$ sebesar -2,015 dengan sig sebesar 0,049 dimana nilai sig $<0,05$ sehingga didapatkan bahwa hipotesis ketiga diterima. Hasil uji hipotesis variabel BOPO didapatkan nilai $\mathrm{t}$ sebesar $-5,413$ dengan sig sebesar 0,000, dimana nilai sig $<0,05$ sehingga didapatkan bahwa hipotesis keempat diterima.

Hasil uji hipotesis secara simultan didapatkan tabel ANOVA sebagai berikut:

Tabel 7. Hasil Uji ANOVA

\begin{tabular}{|c|c|c|c|c|c|c|}
\hline \multicolumn{2}{|c|}{ Model } & $\begin{array}{c}\text { Sum of } \\
\text { Square } \\
\mathrm{S}\end{array}$ & $\begin{array}{l}\mathrm{d} \\
\mathrm{f}\end{array}$ & $\begin{array}{c}\text { Mean } \\
\text { Squar } \\
\mathrm{e} \\
\end{array}$ & $\mathrm{F}$ & Sig. \\
\hline 1 & $\begin{array}{l}\text { Regressio } \\
\mathrm{n}\end{array}$ & 42,558 & 4 & $\begin{array}{r}10,63 \\
9\end{array}$ & $\begin{array}{r}36,30 \\
0\end{array}$ &, $000^{\mathrm{b}}$ \\
\hline & Residual & 13,189 & $\begin{array}{l}4 \\
5\end{array}$ & ,293 & & \\
\hline & Total & 55,747 & $\begin{array}{l}4 \\
9\end{array}$ & & & \\
\hline
\end{tabular}

Sumber : Output SPSS (2019)

Berdasarkan tabel Hasil Uji ANOVA didapatkan nilai $\mathrm{F}$ hitung sebesar 36,300 dan sig sebesar 0,000 dimana nilai sig $<0,05$ sehingga didapatkan bahwa hipotesis kelima diterima.

Hubungan antara variabel CAR terhadap ROA didapatkan koefisien CAR bernilai positif dimana nilai ini menggambarkan bahwa semakin tinggi CAR maka akan semakin meningkatkan profitabilitas (ROA). Dengan tingginya CAR maka kesempatan untuk menambah pendapatan akan semakin besar mengingat CAR akan memberikan kepercayaan kepada investor untuk menanamkan dananya sehingga akan menambah ROA dari pendapatan bunga. Namun hasil uji signifikansi menunjukan bahwa hubungan antara CAR terhadap ROA tidak signifikan ditandai dengan nilai sig > 0,05 hal ini menunjukan bahwa kinerja bank untuk mengukur kecukupan modal yang dimiliki bank agar menunjang aktiva yang mengandung atau menghasilkan risiko seperti kredit tidak sepenuhnya signifikan untuk sampel pada penelitian ini.

Hubungan antara variabel LDR terhadap ROA didapatkan koefisien LDR bernilai negatif dimana nilai ini menggambarkan semakin besar likuiditas yang dikeluarkan untuk kredit akan menyebabkan profitabilitas bank berkurang mengingat semakin besarnya kredit yang diberikan kepada kreditor maka akan meningkatkan risiko terjadinya kredit bermasalah sehingga akan berpengaruh terhadap peluang profitabilitas. Hasil uji $t$ antara variabel LDR terhadap ROA didapatkan nilai sig $<0,05$ hal ini menunjukan bahwa LDR berpengaruh signifikan terhadap profitabilitas bank. Mengingat LDR mencerminkan kemampuan bank dalam mengeluarkan dana pihak ketiga pada kredit untuk menghasilkan pendapatan. Namun besarnya pengaruh akan sangat bergantung kepada keberhasilan dari kredit yang dikeluarkan.

Sesuai dengan hasil studi literature review, peneliti telah merangkum hasil penelitian sebelumnya yang menganalisa faktor-faktor 
terhadap profitabilitas dan dari hasil tersebut didapatkan dinamika hasil penelitian yang menunjang terhadap hipotesis maupun sebaliknya. Hasil penelitian yang menunjukan bahwa CAR secara parsial berpengaruh signifikan terhadap ROA terdapat pada hasil penelitian Syamsuddin (2013), Muin (2017), Wenten (2018), Yusriani, Mus, \& Chalid (2018), Nugroho, Mangantar \& Tulung (2019). Sedangkan hasil penelitian sebaliknya yang menyatakan CAR tidak berpengaruh signifikan terhadap ROA terdapat pada hasil penelitian Hapsari \& Prasetiono (2012), Prasanjaya \& Ramanta (2013), Yogianta (2013), Rahmat, Arfan, \& Musnadi (2014), Fiscal \& Lusiana (2014), Pratiwi \& Wiagustini (2015), Dewi, Mulyadi, \& Abdurrahman (2015), Pamularsih (2015), Hakiim \& Rafsanjani (2016), Wijaya \& Tiyas (2016), Mismiwati (2016), Bilian \& Purwanto (2017), Permatasari, Rahadian, \& Yunita (2017), Fajari \& Sunarto (2017), Sudarmawanti \& Pramono (2017), Dewi, Mardani, \& Salim (2017), Pinasti \& Mustikawati (2018), Ekowati (2018), Munir (2018), Suwarno \& Muthohar (2018), Atmoko, Amboningtyas, \& Fathoni (2018), Purwanto (2018), Pandoyo (2019), Febrianti \& Ladinus (2019), Pratama \& Isynuwardhana (2019), Suci (2019), Maghfiroh, Dewi, \& Suhendro (2019), Susilowati \& Tiningrum (2019), Setiawan, Amboningtyas, \& Aryanti (2019), Nisa (2019), Fernando \& Dewi (2019), Nanda, Hasan, \& Aristyanto (2019).

Sementara hasil penelitian yang menganalisa pengaruh hubungan antara LDR terhadap ROA dan menghasilkan hipotesis secara parsial yang signifikan terdapat pada penelitian Prasanjaya \& Ramanta (2013), Yogianta (2013), Hapsari \& Prasetiono (2012), Rahmat et al. (2014), Pamularsih (2015), Dewi, Herawati, \& Sulindawati (2015), Julaeha (2015), Mismiwati (2016), Sudarmawanti \& Pramono (2017), Ekowati (2018), Yusriani et al. (2018), Susilowati \& Tiningrum (2019), Nisa (2019), Fernando \& Dewi (2019). Sementara hasil penelitian sebaliknya yang menyatakan hasil yang tidak signifikan antara LDR terhadap ROA terdapat pada penelitian Syamsuddin (2013), Rahmat, Arfan dan Musnadi (2014), Fiscal \& Lusiana (2014), Pratiwi \& Wiagustini (2015), Dewi, Mulyadi \& Abdurrakhman (2015), Wijaya \& Tiyas (2016), Bilian \& Purwanto (2016), Fajari \& Sunarto (2017), Wenten (2017), Muin (2017), Pinasti \& Mustikawati (2018), Masril (2018), Purwanto (2018), Rohmiati, Winarni, \& Soebroto (2019), Pandoyo (2019), Febrianti \& Ladinus (2019), Pratama \& Isynuwardhana (2019), Suci (2019), Magfiroh, Dewi \& Suhendro (2019), Atmoko, Amboningtyas \& Fathoni (2019).

Hasil penelitian lainnya yang menganalisa pengaruh hubungan antara NPL terhadap ROA dan mendapatkan hasil yang signifikan terdapat pada penelitian Yogianta (2013), Syamsuddin (2013), Rahmat, Arfan dan Musnadi (2014), Dewi, Mulyadi
\& Abdurrakhman (2015), Pamularsih (2015), Dewi, Herawati \& Sulindawati (2015), Julaeha (2015), Wijaya \& Tiyas (2016), Fajari \& Sunarto (2017), Sudarmawanti \& Pramono (2017), Ekowati (2018), Purwanto (2018), Yusriani, Mus \& Chalid (2018), Pratama \& Isynuwardhana (2019) Suci (2019), Atmoko, Amboningtyas \& Fathoni (2019), Setiawan, Amboningtyas \& Aryanti (2019), Nisa' (2019), Fernando \& Dewi (2019). Sementara hasil penelitian sebaliknya yang mendapatkan hubungan tidak signifikan secara parsial antara NPL terhadap ROA terdapat pada hasil penelitian Hapsari \& Prasetiono (2013), Pratiwi \& Wiagustini (2015), Mismiwati (2016), Wenten (2017), Muin (2017), Dewi, Mardani \& Salim (2017), Pinasti \& Mustikawati (2018), Masril (2018), Rohmiati, Winarni \& Soebroto (2019), Pandoyo (2019), Febrianti \& Ladinus (2019), Magfiroh, Dewi \& Suhendro (2019), Susilowati \& Tiningrum (2019), Nugroho, Mangantar \& Tulung (2019).

Berdasarkan hasil penelitian yang menganalisa pengaruh hubungan secara parsial antara variabel BOPO terhadap ROA dan mendapatkan hasil yang signifikan terdapat pada penelitian Prasanjaya \& Ramatha (2013), Yogianta (2013), Hapsari \& Prasetiono (2013), Syamsuddin (2013), Rahmat, Arfan dan Musnadi (2014), Fiscal \& Lusiana (2014), Pratiwi \& Wiagustini (2015), Pamularsih (2015), Dewi, Herawati \& Sulindawati (2015), Hakiim \& Rafsanjani (2016), Wijaya \& Tiyas (2016), Mismiwati (2016), Bilian \& Purwanto (2016), Permatasari, Rahardian \& Yunita (2017), Fajari \& Sunarto (2017), Sudarmawanti \& Pramono (2017), Wenten (2017), Muin (2017), Dewi, Mardani \& Salim (2017), Pinasti \& Mustikawati (2018), Yusriani, Mus \& Chalid (2018), Suwarno \& Muthohar (2018), Rohmiati, Winarni \& Soebroto (2019), Pandoyo (2019), Febrianti \& Ladinus (2019), Pratama \& Isynuwardhana (2019), Suci (2019), Magfiroh, Dewi \& Suhendro (2019), Susilowati \& Tiningrum (2019), Setiawan, Amboningtyas \& Aryanti (2019), Nisa' (2019), Fernando \& Dewi (2019), Nanda, Hasan \& Aristyanto (2019). Sementara hasil sebaliknya yang mendapatkan hubungan tidak signifikan antara BOPO terhadap ROA terdapat pada hasil penelitian Julaeha (2015), Nugroho, Mangantar \& Tulung (2019).

Melihat hasil penelitian ini ternyata hubungan antara variabel NPL terhadap ROA didapatkaan koefisien regresi bernilai negatif hal ini menunjukan bahwa semakin tinggi kredit yang bermasalah maka akan semakin mengurangi profitabilitas bank. Hasil uji $\mathrm{t}$ didapatkan nilai sig $<0,05$ dimana nilai ini menunjukan pegaruh yang signifikan antara NPL terhadap ROA. Hasil ini menggambarkan bahwa rasio yang digunakan untuk mengukur kemampuan bank dalam menangani risiko kegagalan pengembalian kredit oleh debitur berpengaruh 
signifikan terhadap tingkat profitabilitas bank, karena akan mengurangi laba yang diperoleh bank.

Hubungan antara variabel BOPO terhadap ROA didapatkan koefisien regresi bernilai negatif, hal ini menunjukan bahwa semakin tinggi biaya operasional maka akan menyebabkan terpakainya profitabilitas yang seharusnya didapatkan oleh bank dan hal ini menggambarkan ketidakefisienan bank dalam mengelola kegiatan operasionalnya. Hasil uji t didapatkan nilai sig $<0,05$ dimana nilai ini menunjukan pengaruh yang signifikan antara BOPO terhadap ROA. Semkain kecil rasio BOPO maka maka efisiensi biaya operasional yang dikeluarkan bank yang bersangkutan semakin baik sehingga kemungkinan bank dalam kondisi bermasalah akan semakin kecil.

Hubungan antara variabel CAR, LDR, NPL dan BOPO terhadap ROA secara simultan didapatkan nilai $\mathrm{F}$ hitung memiliki nilai sig $<0,05$ dimana nilai ini menunjukan bahwa secara simultan keempat rasio berpengaruh signifikan terhadap ROA. Dengan pengaruh yang bergantung kepada nilai dari masing-masing koefisien regresi yang dihasilkan untuk masing-masing variabel tersebut. besarnya pengaruh yang didapatkan sebesar $74,2 \%$ dimana nilai ini masuk kedalam kriteria tinggi sehingga, rasio yang diukur pada model penelitian ini hausnlah diperhatikan oleh setiap bank dlam mengukur kinerjanya sehingga akan mampu mengontrol tingkat profitabilitas yang diharapkan oleh bank.

\section{KESIMPULAN}

Berdasarkan hasil penelitian dan analisis di atas terhadap pengaruh rasio kecukupan modal, likuiditas, risiko kredit dan efisinesi biaya terhadap profitabilitas terhadap 10 bank go public dengan nilai asset terbesar, maka dapat disimpulkan sebagai berikut:

1. Hasil uji $\mathrm{t}$ variabel rasio kecukupan modal (CAR) terhadap profitabilitas (ROA) memiliki pengaruh positif namun tidak signifikan, dengan demikian maka hipotesis pertama ditolak.

2. Hasil uji $\mathrm{t}$ variabel rasio likuiditas (LDR) terhadap profitabilitas (ROA) memiliki pengaruh negatif dan signifikan, dengan demikian maka hipotesis kedua diterima.

3. Hasil uji t variabel rasio risiko kredit (NPL) terhadap profitabilitas (ROA) memiliki pengaruh negatif dan signifikan dengan demikian hipotesis ketiga diterima.

4. Hasil uji $t$ variabel rasio efisiensi biaya operasional (BOPO) terhadap profitabilitas (ROA) memiliki pengaruh negatif dan signifikan dengan demikian hipotesis keempat diterima.

5. Hasil uji $F$ variabel rasio kecukupan modal (CAR), likuiditas (LDR), risiko kredit (NPL) dan efisiensi biaya (BOPO) terhadap profitabilitas (ROA) memiliki pengaruh yang signifikan.
Sementara besarnya pengaruh secara simultan didapatkan sebesar 74,2\% sedangkan sisanya sebesar $25,8 \%$ dipengaruhi variabel diluar model penelitian ini. Hasil persamaan regresi didapatkan $\mathrm{ROA}=9,212+0,049 \mathrm{CAR}$ 0,037LDR - 0,238NPL - 0,050BOPO.

Penelitian ini diharapkan dapat berguna bagi pihak terkait seperti pihak bank agar manajemen bank dapat meningkatkan rasio CAR, menekan rasio BOPO dan NPL serta memperhitungkan kembali LDR yang berpotensi memiliki risiko besar terhadap timbulnya kredit bermasalah, namun meningkatkan likuiditas terhadap investasi kredit yang berpeluang besar terhadap peningkatan profitabilitas.

Disarankan juga bagi peneliti selanjutnya untuk menambahkan faktor-faktor eksternal yang memungkinkan mempengaruhi terhadap profitabilitas bank seperti suku bunga, tingkat inflasi dan juga pertumbuhan ekonomi secara nasional. Serta menggunakan jangka waktu yang lebih panjang sehingga hasil yang didapatkan akan lebih dapat digeneralisasikan.

\section{REFERENSI}

Atmoko, A. S., Amboningtyas, D., \& Fathoni, A. (2018). Effectof LDR, NPL and BOPO on Profitabilitas Based on CAR. Journal of Management, 4(4), 1-17.

Bilian, F., \& Purwanto. (2017). Analisis Pengaruh CAR, NIM, BOPO, dan LDR Terhadap Profitabilitas Bank Persero. FIRM Journal of Management Studies, 2(1), 155-168.

Dewi, L. E., Herawati, N. T., \& Sulindawati, L. G. E. (2015). Analisis Pengaruh NIM, BOPO, LDR dan NPL Terhadap Profitabilitas (Studi Kasus Pada Bank Umum Swasta Nasional Yang Terdaftar Pada Bursa Efek Indonesia Periode 2009-2013). E-Journal S1 Ak. Universitas Pendidikan Ganesha, 3(1), 1-11.

Dewi, N. V., Mardani, R. M., \& Salim, M. A. (2017). Pengaruh CAR, NPL, NIM dan BOPO Terhadap Profitabilitas Perbankan (Studi Kasus Pada Bank Umum Yang Terdaftar di Bursa Efek Indonesia Tahun 2012-2015). Jurnal Ilmiah Riset Manajemen, 6(1), 70-87.

Dewi, P. K., Mulyadi, \& Abdurrahman. (2015). Analsis Pengaruh CAR, NPL, LDR dan NIM Terhadap Profitabilitas Perbankan (Studi Kasus Pada Bank Umum Yang Tercatat Pada BEI Tahun 2008-2012). JAFFA, 3(1), 17-30.

Ekowati, A. R. (2018). Pengaruh CAR, LDR, NPL, Kepemilikan Asing Terhadap Profitabilitas (ROA) Pada Bank Konvensional Devisa Periode 2012-2017. Artikel Ilmiah Sekolah Tinggi Ilmu Ekonomi Perbanas, 160-164.

Fajari, S., \& Sunarto. (2017). Terhadap Profitabilitas Bank (Studi Kasus Perusahaan Perbankan Yang Tercatat di Bursa Efek Indonesia Periode Tahun 2011 sampai 2015). In 
Prosiding Seminar Nasional Multi Disiplin Ilmu \& Call For Papers Unisbank Ke-3 (SENDI_U 3) (Vol. 3, pp. 853-862).

Febrianti, S., \& Ladinus. (2019). Analisis Rasio Keuangan Dalam Memprediksi Tingkat Profitabilitas Bank Umum Konvensional (Studi Pada Bank Umum Yang Listing di BEI Periode 2012-2016). In Prosiding Seminar Nasional Pakar (pp. 1-6).

Fernando, R., \& Dewi, A. S. (2019). Pengaruh CAR, BOPO, NPL, NIM, dan LDR terhadap ROA Pada Perusahaan di Sektor Perbankan Yang terdaftar di BEI Periode 2012-2016. https://doi.org/10.31219/OSF.IO/K3W69

Fiscal, Y., \& Lusiana, L. (2014). Pengaruh Capital Adequacy Ratio (CAR), Loan to Deposit Ratio (LDR), Biaya Operasional Pendapatan Operasional (BOPO), terhadap Profitablitas BPR (Studi Kasus Pada BPR di provinsi Lampung Tahun 2010-2012). Jurnal Akuntansi \& Keuangan, 5(2), 127-158.

Hakiim, N., \& Rafsanjani, H. (2016). Pengaruh Internal Capital Adequency Ratio (CAR), Financing To Deposit Ratio (FDR), dan Biaya Operasional Per Pendapatan Operasional (BOPO) dalam Peningkatan Profitabilitas Industri Bank Syariah di Indonesia. Jurnal Aplikasi Manajemen (JAM), 14(1), 161-168. https://doi.org/10.32833/majem.v7i1.55

Hapsari, T. K., \& Prasetiono. (2012). Analysis The Influence of CAR, NPL, BOPO, LDR, GMW, and Concentrate Ratio to The ROA (Study to General Bank that listing in Indonesia Stock Exchange 2005-2009). In Sustainable Competitive Advantage 2 (SCA-2) (pp. 1-31).

Julaeha, L. (2015). Pengaruh Non Performing Loan, Net Interest Margin, Biaya Operasional /Pendapatan Operasional dan Loan to Deposit Ratio Terhadap Profitabilitas Bank (Studi Kasus Bank Rakyat Indonesia, Tbk Periode 2003-2014). Jurnal Ilmiah Ekonomi Bisnis, 20(3).

Maghfiroh, A. U., Dewi, R. R., \& Suhendro. (2019). Faktor-Faktor Yang Mempengaruhi Profitabilitas Perbankan Studi Empiris Pada Perbankan Yang Terdaftar di BEI Periode 2014-2017. In Proseding Seminar Nasional Akuntansi (pp. 1-12).

Masril. (2018). LDR, NPL, dan Harga Saham Yang Mempengaruhi Terhadap ROA dengan Jumlah Asset Sebagai Moderating Pada PErbankan di BEI. Asian Journal of Innovation and Entrepreneurship, 3(2), 107-115.

Mismiwati. (2016). Pengaruh CAR, NIM, BOPO, LDR dan NPL Terhadap ROA (Studi Pada PT BPD Sumsel Babel). I-Finance, 2(1), 55-74.

Muin, S. A. (2017). Analisis Faktor-Faktor Yang Mempengaruhi Rentablitas Pada PT. Bank Rakyat Indonesia (Persero), Tbk. Periode 2011-2016. Jurnal Economix, 5(2), 203-214.
Munir, M. (2018). Analisis Pengaruh CAR, NPF, FDR dan Inflasi terhadap Profitabilitas Perbankan Syariah di Indonesia. Ihtifaz: Journal of Islamic Economics, Finance, and Banking, $1(1), \quad 89$. https://doi.org/10.12928/ijiefb.v1i1.285

Nanda, A. S., Hasan, A. F., \& Aristyanto, E. (2019). Pengaruh CAR dan BOPO Terhadap ROA pada Bank Syariah pada Tahun 2011-2018 (The Effect of CAR and BOPO Against ROA in Islamic Banking in 2011-2018). Perisai : Islamic Banking and Finance Journal, 3(1), 19. https://doi.org/10.21070/perisai.v3i1.2160

Nisa', K. (2019). Analisis Pengaruh CAR, LDR, BOPO, NIM dan NPL terhadap ROA dengan Board Size Sebagai Variabel Kontrol (Studi Empiris Pada Bank Umum Konvensional Go Public di Indonesia Periode 2013-2017).

Nugroho, D., Mangantar, M., \& Tulung, J. E. (2019). Pengaruh CAR, BPO, NIM, dan NPL terhadap ROA Industri Bank Umum Swasta Nasional Buku 3 Periode 2014-2018. Jurnal EMBA, 7(3), 4222-4229.

Pamularsih, D. (2015). Pengaruh LDR, NPL, NIM, BOPO, CAR dan Suku Bunga Terhadap Profitabilitas Pada Sektor Perbankan Yang Terdaftar di Bursa Efek Indonesia Periode Tahun 2009-2013. Jurnal Ilmiah Mahasiswa S1 Akuntansi Universitas Pandanaran, 1(1), $1-20$.

Pandoyo, P. (2019). Faktor-Faktor Yang Mempengaruhi Profitabilitas Bank Bpr Di Provinsi Jawa Barat. Jurnal Riset Manajemen Dan Bisnis (JRMB) Fakultas Ekonomi UNIAT, 4(1), 127-136. https://doi.org/10.36226/jrmb.v4i1.247

Permatasari, A. N., Rahadian, D., \& Yunita, I. (2017). Pengaruh CAR, LDR, BOPO, NPL dan Ukuran Perusahaan Terhadap Profitabilitas (Studi Kasus Pada Bank Umum Swasta Nasional Devisa dan Bank Umum Swasta Nasional Non Devisa di Indonesia Periode 2012-2015). In e-Proceeding of Management (Vol. 4, pp. 1296-1303).

Pinasti, W. F., \& Mustikawati, R. I. (2018). Pengaruh Car, Bopo, Npl, Nim Dan Ldr Terhadap Profitabilitas Bank Umum Periode 2011-2015. Nominal, Barometer Riset Akuntansi Dan Manajemen, 7(1). https://doi.org/10.21831/nominal.v7i1.19365

Prasanjaya, A. A. Y., \& Ramanta, I. W. (2013). Analisis Pengaruh Rasio Car, Bopo, Ldr Dan Ukuran Perusahaan Terhadap Profitabilitas Bank Yang Terdaftar Di Bei. E-Jurnal Akuntansi, 4(1), 230-245.

Pratama, E., \& Isynuwardhana, D. (2019). Pengaruh CAR, NPL, LDR dan BOPO Terhadap Profitabilitas Pada Industri Perbankan (Studi Kasus Pada Bank Umum Yang Terdaftar di Bursa Efek Indonesia Tahun 2012-2017). In 
eProceedings of Management (Vol. 6, pp. 634-644).

Pratiwi, L. P. S. W., \& Wiagustini, N. L. P. (2015). Pengaruh CAR, BOPO, NPL dan LDR Terhadap Profitabilitas. E-Jurnal Manajemen Universitas Udayana, 5(4), 2137-2166.

Purwanto, I. S. D. (2018). Pengaruh Non Perforning Loan, Loan To Deposit Ratio Dan Capital Adequacy Ratio Terhadap Profitabilitas Pada Perusahaan Perbankan Yang Terdaftar Di Bursa Efek Indonesia Periode 2014-2016. Jurnal Perilaku Dan Strategi Bisnis, 6(2), 122-136. https://doi.org/10.26486/jpsb.v6i2.561

Rahmat, Arfan, M., \& Musnadi, S. (2014). Pengaruh Capital Adequacy Ratio, Biaya Operasional Pendapatan Operasional, Non Performing Loan, Net Interest Margin, dan Loan to Deposit Ratio Terhadap Profitabilitas Bank (Studi Pada Bank Persero di Indonesia Periode 2002-2013). Jurnal Akuntansi Pascasarjana Universitas Syiah Kuala, 3(2), 85-93.

Rohmiati, E., Winarni, \& Soebroto, N. W. (2019). Terhadap Profitabilitas Pada Bank Umum Di Indonesia Periode 2012-2017. Keunis Majalah Ilmiah, 7(1), 34-48.

Setiawan, M., Amboningtyas, D., \& Aryanti, R. P. (2019). Analysis of Non Performing Loan (NPL), Capital Adequacy Ratio (CAR), and Operational Cost With Operational Income (BOPO) That Impact on Profitability (Case Study in PT. BPR in Semarang Area 20132017). Journal of Management, 5(5), 1-10.

Suci, D. P. (2019). Pengaruh CAR, NPL, NIM, BOPO, dan LDR terhadap Profitabilitas Perbankan di Indonesia Yang Terdaftar di BEI Periode 2014-2017. Universitas Muhammadiyah Surakarta.

Sudarmawanti, E., \& Pramono, J. (2017). Pengaruh CAR, NPL, BOPO, NIM dan LDR terhadap ROA (Studi Kasus Pada Bank Perkreditan Rakyat di Salatiga Yang Terdaftar di Otoritas Jasa Keuangan Tahun 2011-2015). Among Makarti, 10(19), 1-18.
Susilowati, E. M., \& Tiningrum, E. (2019). Tata Kelola Perbankan di Tinjau dari Kinerja Keuangan dilihat dari Profitabilitas Perbankan. ProBank: Jurnal Ekonomi Dan Perbankan, 4(1), 9-14.

Suwarno, R. C., \& Muthohar, A. M. (2018). Analisis Pengaruh NPF, FDR, BOPO, CAR, dan GCG terhadap Kinerja Keuangan Bank Umum Syariah di Indonesia Periode 2013-2017. BISNIS : Jurnal Bisnis Dan Manajemen Islam, 6(1),

94. https://doi.org/10.21043/bisnis.v6i1.3699

Syamsuddin. (2013). Pengaruh Capital Adequacy Ratio (CAR), Non Performing Loan (NPL), Biaya Operasional Pendapatan Operasional (BOPO), Loan to Deposit Ratio (LDR), dan Net Interest Margin (NIM) Terhadap Profitabilitas (ROA). Business \& Management Journal, 10(1), 1-14.

Wenten, I. ketut. (2018). Analisis CAR, NPL, BOPO, NIM, LDR dan pengaruhnya terhadap profitabilitas pada bank artha graha internasional tbk. Jurnal Akuntansi Barelang, 2(2), 74-93.

Wijaya, E., \& Tiyas, A. W. (2016). Analisis Pengaruh Kecukupan Modal , Likuditas , Risiko Kredit dan Efisiensi Biaya Terhadap Profitabilitas Bank Umum. Jurnal Ekonomi, Manajemen Dan Perbankan, 2(3), 99-109.

Yogianta, C. W. E. (2013). Analisis Pengaruh Car, Nim, Ldr, Npl Dan Bopo Terhadap Profitabilitas Studi Pada Bank Umum Yang Go Publik Di Bursa Efek Indonesia Periode Tahun 2002-2010. Jurnal Bisnis Strategi, 22(2), 94-111.

Yusriani, Mus, A. R., \& Chalid, L. (2018). Pengaruh CAR, NPL, BOPO dan LDR Terhadap Profitabilitas Pada Bank Umum Milik Negara Persero Di Bursa Efek Indonesia. Jurnal Riset Edisi XXV, 4(2), 1-17. https://doi.org/10.1017/CBO9781107415324.0 04 